\title{
Overview of the History of the Cranial Nerves: From Galen to the 21st Century
}

\author{
MARÍA ISABEL PORRAS-GALLO $\mathbb{D}^{1,1,2 *}$ ÁNGEL PEÑA-MELIÁN ${ }^{\circledR},{ }^{3}$ \\ FERMÍN VIEJO, ${ }^{3}$ TOMÁS HERNÁNDEZ, ${ }^{4}$ EDUARDO PUELLES $\mathbb{}{ }^{\circ},{ }^{5}$ \\ DIEGO ECHEVARRIA, ${ }^{5}$ AND JOSÉ RAMÓN SAÑUDO $\mathbb{1}^{3}$ \\ ${ }^{1}$ Department of Medical Sciences, Medical Faculty of Ciudad Real, University of Castilla-La \\ Mancha, Ciudad Real, Spain \\ ${ }^{2}$ Regional Center of Biomedical Research (CRIB), University of Castilla-La Mancha, Ciudad \\ Real, Spain \\ ${ }^{3}$ Department of Human Anatomy and Embryology, Facultad de Medicina, Universidad \\ Complutense de Madrid, Madrid, Spain \\ ${ }^{4}$ Department of Human Anatomy and Embryology, Universitat de Vàlencia, Valencia, Spain \\ ${ }^{5}$ Department of Histology and Anatomy, University of Miguel Hernández, Alicante, Spain
}

\begin{abstract}
Throughout history the description and classification of the cranial nerves has been linked to the development and characteristics of anatomy and the role that it played as a tool in providing rationality to medicine, together with social, cultural, religious, and philosophical factors. Anatomists were interested in the cranial nerves, but they disagreed on their number and their paths. We can divide the history of the cranial nerves into three different periods: the first, early or macroscopic period; the second or microscopic period; and the third period or ontogenesis and genoarchitecture. The main aim of this article is to show how the description and knowledge of the cranial nerves were developed in the course of these three periods, and to highlight the main changes produced and the factors related to these changes. We describe how the first period was mainly focused on establishing the definition, number and paths of the cranial nerves, through contributions ranging from Galen's studies in the second century to Sömmerring's Doctoral Dissertation in 1778 that described 12 cranial nerves for the first time. Then, the microscopic period was concentrated on the identification of the real nuclei of origin of the different cranial nerves located in the brain stem. Finally came the third period, or ontogenesis and genoarchitecture of the rhombecephalic and mesencephalic cranial nerve nuclei. Anat Rec, 302:381-393, 2019. @ 2018 Wiley Periodicals, Inc.
\end{abstract}

Key words: cranial nerves; history of cranial nerves; nuclei of the cranial nerves; genoarchitecture of cranial nerves

\section{INTRODUCTION}

Throughout history the description and classification of the cranial nerves has been linked to the development and characteristics of anatomy and the role that it

*Correspondence to: María-Isabel Porras Gallo, Department of Medical Sciences, Faculty of Medicine of Ciudad Real/CRIB, University of Castilla-La Mancha, Camino de Moledores s/n, 13071 Ciudad Real, Spain.

E-mail: mariaisabel.porras@uclm.es played as a tool in providing rationality to medicine, together with social, cultural, religious, and philosophical factors.

As we shall show later, anatomists were interested in the cranial nerves, and their books contain much

Received 18 May 2018; Revised 25 July 2018; Accepted 27 July 2018.

DOI: $10.1002 / a r .23928$

Published online 9 November 2018 in Wiley Online Library (wileyonlinelibrary.com). 
information about them, either in anatomical treatises or specific books focused on one of the cranial nerves; but they disagreed on their number and their paths.

We can divide the history of the cranial nerves into three different periods: the first, early or macroscopic period; the second or microscopic period; and the third period or ontogenesis and genoarchitecture.

The first, early or macroscopic period started with human anatomy at the service of medicine, based on dissection-first, exclusively of animals and later, mainly of humans-and ended with the rise to predominance of microscopic anatomy. This period was mainly focused on establishing the definition, number and paths of the cranial nerves, through contributions ranging from Galen's studies in the second century to Sömmerring's Doctoral Dissertation in 1778 that described 12 cranial nerves for the first time.

The second period or microscopic period was concentrated on the identification of the real nuclei of origin of the different cranial nerves located in the brain stem.

Finally came the third period, or ontogenesis and genoarchitecture of the rhombecephalic and mesencephalic cranial nerve nuclei.

\section{From Galen to Sömmerring (1755-1830) via the Great Fallopius (1523-1562)}

Although classical Greek medicine was the first rational and scientific medicine, anatomy did not achieve total and widespread status as a service to medicine until Galen (129-200 AD) (Singer, 1957). Before him we can point to the first period of Alexandrian anatomy (third century BC). During this period a group of physicians took advantage of the importance Alexandria had acquired as a great scientific center (Mandressi, 2003), and carried out anatomical research based on the dissection of human cadavers and vivisections of condemned slaves as Ludwig Edelstein described (Temkin, Temkin, 1967; García Ballester, 1974). One of the results of Alexandrian anatomy was the establishment for the first time of nervous anatomy (Walshe, 2016). Together with Erasistratus (304-250 BC), Herophilus (335-280 BC) was one of the main members of this Alexandrian school; and provided us with the first reference to the cranial nerves. According to García Ballester, he mentioned seven cranial nerves (García Ballester, 1974). However, we have no further information about this, because his legacy was burnt with the Alexandrian library (Keele, 1961). However, it seems that before this time Alcmaeon of Croton (6th-5th centuries BC), a member of the Pythagorean School, had superficially described the optic nerve and chiasma (Acuña et al., 2010).

Galen, relying on the previous anatomical legacy, particularly that of the Alexandrian anatomist Marinus (ca. $130 \mathrm{AD}$ ), who wrote about the cranial nerves, put anatomy to the service of medicine. This anatomy-or more exactly anatomo-physiology - was the study of human beings, and therefore it was strictly necessary to acquire knowledge through dissection; however, only dissection of animals was accepted at that moment, precluding human dissection. Based on the establishment of analogies among discoveries from dissections and vivisections of animals, together with observations of skeletons and cadavers and the study of previous anatomical knowledge, Galen gained human anatomical knowledge [Edelstein (Temkin and Temkin, 1967); French, 1993;
García Ballester, 1972, Laín Entralgo, 1978]. Despite the validity of Galen's procedure (Savage Smith, 1971a), this method led to some errors in his anatomical descriptions, due to the differences between animal and human structures and functions, and occasionally made his descriptions difficult to understand.

Galen organized and structured anatomical knowledge and, for the first time, wrote proper anatomicaly treatises (García Ballester, 1974), which included information about the cranial nerves. He identified seven cranial nerves and numbered them from anterior to posterior, keeping the order established by his mentor Marinus (Savage Smith, 1971a). In fact, Galen's classification included seven pairs: I, optic; II, oculomotor; III and IV, trigeminal; V, facial and auditory; VI, glossopharyngeal, vagus and accessory; VII, hypoglossal (Savage Smith, 1971a,b; López Salvá, 2002). Galen's description of the cranial nerves was recorded in his anatomical treatises: De usu partium and De anatomicis administrationibus (Savage Smith, 1971a,b; López Salvá, 2002). The contents of the former were based on dissections of oxen, pigs, dogs and donkeys and the latter mainly on dissections of apes.

Medieval physicians realized at the end of the thirteenth century that the rationality of medicine lies in its anatomical basis, thanks to significant religious, cultural, judicial changes (Mandressi, 2003) and to their rediscovery of Galen's philosophical, rational and, particularly, anatomical medicine. Human dissection thus became essential to produce real medicine, and to show medicine as a true scientia (French, 1993, p 83). This was fundamental to avoid the exclusion of medicine from the new universities. As Mandressi (2003) has pointed out, this new situation was the result of being sure that medical, judicial and religious answers were inside the human cadaver, and that they would be discoverable by eye. So human dissections were progressively incorporated into medical teaching at the new universities, and anatomy was transformed, although it continued to be anatomo-physiology until the seventeenth century.

Galen's descriptions of cranial nerves were still valid for at least 1,200 years until the Italian Renaissance, when the dissection of human cadavers started to reveal the errors of the analogies he had made (Savage, 1971a, b). However, this correction was not quickly established.

The Bologna anatomist, Mondino de' Liuzzi (1265-1326), also maintained a classification of seven pairs in his Anothomia (1316), the first modern anatomical text based on the dissection of human cadavers (Mandressi, 2003). His seven cranial nerves were: I, optic; II, oculomotor; III, abducens; IV, trigeminal; V, facial; VI, vagus, and VII, glossopharyngeal (Acuña et al., 2010).

It is important to point out that illustrations became a key element of this new emerging human anatomy. They were incorporated into anatomy texts and were used as a way of quickly circulating new morphological discoveries that were not yet included in the text. One example of this was Guido da Vigevano (1280-1349), Mondino de' Liuzzi's student, who included a representation of two holes corresponding to the olfactory nerves in a drawing in his Anothomia (1345) (Acuña et al., 2010). Two centuries later this practice became more prominent. Indeed Andreas Vesalius (1514-1564) clarified the path of the cranial nerves with his illustrations, and Bartolomeo Eustachius (1500 or 1510-1574) also depicted this path even better than Vesalius, although his works were published several years after his death (Acuña et al., 2010). 


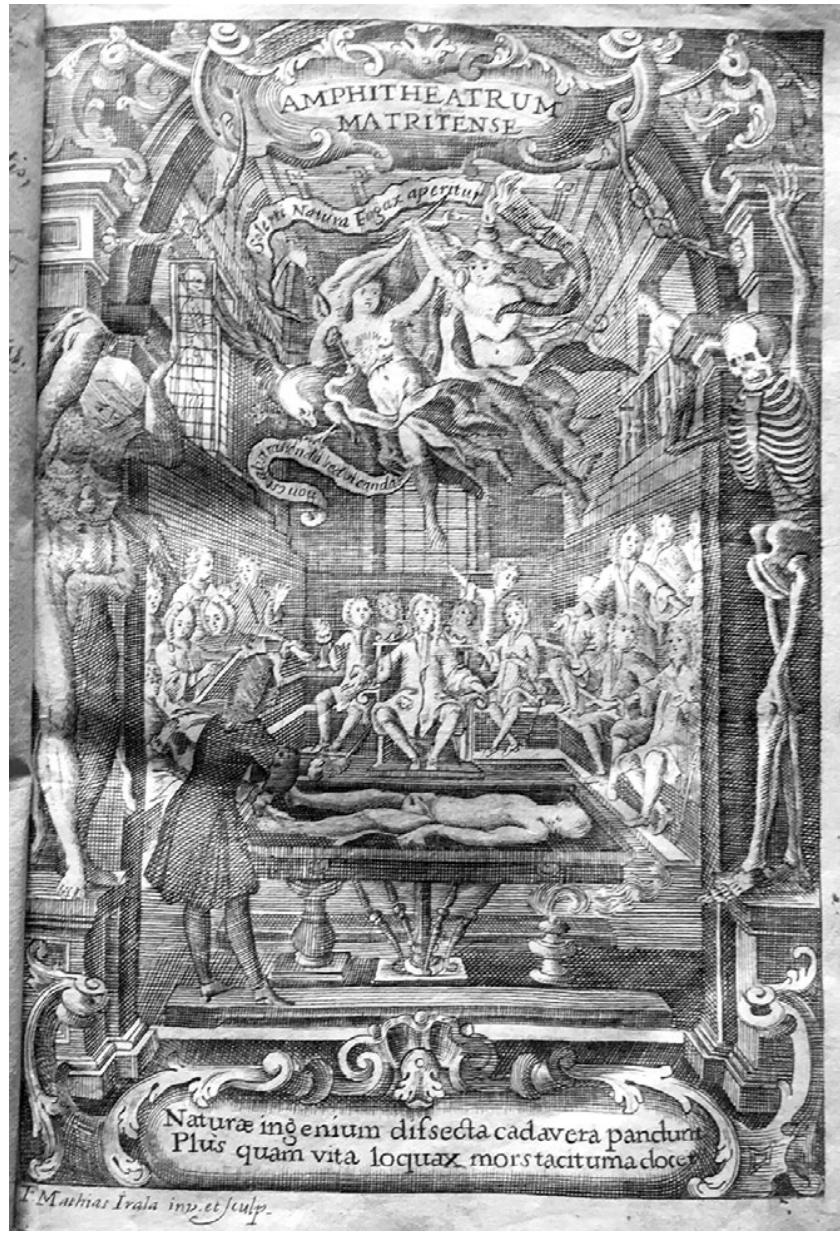

Fig. 1. Portrait of the Martin Martinez's Book (1757) showing the classical disposition of the amphitheater at the moment of perform a public dissection with the Professor just on the center sat on his Chair, the Reader on the left and the Prosector close to the dissecting table that was established by Vesalius for the first time. Martínez M. 1757. Anatomía Completa del hombre pp: 362-391. Madrid: Viuda de Jofeph de Orga.

Strangely enough, concerning the cranial pairs the main contributors to this new anatomy were not Jacopo Berengario da Carpi (1460-1530) with his Anatomia Carpi, published in 1535, Andreas Vesalius with his De Humani Corporis Fabrica (Vesalius, 1997 [original: 1543]) or Charles Estienne and his De Dissectione partium corporis humani (1546), but other members of the Paduan School, such as Bartolomeo Eustachius with his Opuscula anatomica (1564), Realdo Colombo (1544-1559) with his De Re Anatomica, Gabriele Fallopius with his Observationes anatomicae (1561) or Fabrizi d'Acquapendente (1537-1619), who clarified much of the confusion regarding the anatomy of the different cranial nerves (Flamm, 1967; Shaw, 1992). However, they do not substantially change the concepts of cranial nerves reported by Galen (Savage Smith, 1971a,b; Laín Entralgo, 1978). Thus, the description of the cranial nerves, with few exceptions, survived until the eighteenth century in spite of the fact that anatomists of the seventeenth and eighteenth centuries were well aware that it was not correct (Bonnels \& Lacaba, 1799).
After Vesalius, during the sixteenth and seventeenth centuries many different anatomists improved the descriptions of the cranial nerves, but they did not substantially modify the formula proposed by Galen (Table 1).

The optic nerve was considered the 1st cranial until the seventeenth century when Gaspar Bartholin father, in 1611, suggested and introduced the nervus olfactorius as the first cranial nerve (Porzionato et al., 2013). However, some authors consider that Alessandro Benedetti (1450-1512) was the first to list the olfactory tracts as the first pair of cranial nerves in 1502; others that it was Thomas Willis (1621-1675) in 1664 (Flamm, 1967; Shaw, 1992) (Figs. 2 and 3).

Concerning the second cranial nerve, Eustachius (1552), Colombo (1559), and Fallopius (1561) differentiated it into three different nerves: the oculomotor, trochlear and abducens (Flamm, 1967). Fallopius's classification maintained the oculomotor as the second pair, but allocated the abducens as the fourth and the trochlear as a new pair, the eighth cranial nerve (Flamm, 1967).

For the third cranial nerve, again Fallopius made an accurate description describing for the first time three branches of the trigeminal nerve that were later consolidated with their modern names-ophthalmic, superior and inferior maxillary-by Meckel in 1748 (Flamm, 1967) (Fig. 3).

Regarding the fifth cranial nerves, it was again Fallopius who accurately described the structure of the facial canal inside the temporal bone and discussed the length of its entrance and exit points (Macchi et al., 2014). Thomas Willis was the first to name it as the trigeminal nerve in 1664 . The accurate relation of its ganglion was established by Hirsh in 1765 (Sonig et al., 2013). Wrisberg in 1777 precisely described the nervus intermedius as part of the facial nerve (Tubbs et al., 2014) (Figs. 2 and 3). It was Sömmerring in 1778 who for the first time described the facial and auditory nerves as two different nerves, and gave them two different numbers: VII for the facial and VIII for the auditory nerves (Corrales et al., 2017).

Fallopius was able to identify the sixth cranial nerves as two nerves: glossopharyngeal and vagus, without mentioning the accessory (Flamm, 1967). It was Willis in 1664 who considered the spinal accessory as a separate cranial nerve (Fig. 2). This concept was consolidated by Sömmering in 1778, when he described three different nerves: glossopharyngeal, vagus and accessorius (Flamm, 1967).

Finally, Galen's seventh cranial nerve came to be considered as the hypoglossal nerve and the twelfth cranial nerve by Sömmerring (Flamm, 1967) (Table 1).

\section{System of the 12 Cranial Nerves}

From the sixteenth until the eighteenth centuries several anatomists tried to find different Galen patterns: 8 cranial nerves, Fallopius (1562); 9 cranial nerves, Colombo (1559); 9 cranial nerves, Willis (1664); 13 cranial nerves, Vicq d'Azir (1776) (Martinez, 1757; Bonnels \& Lacaba, 1799; Flamm, 1967; Shaw, 1992; Corrales et al., 2017); and Vincenzo Malacarne in his book Encefalotomia Universial described 17 cranial nerves (Bonnels \& Lacaba, 1799). 

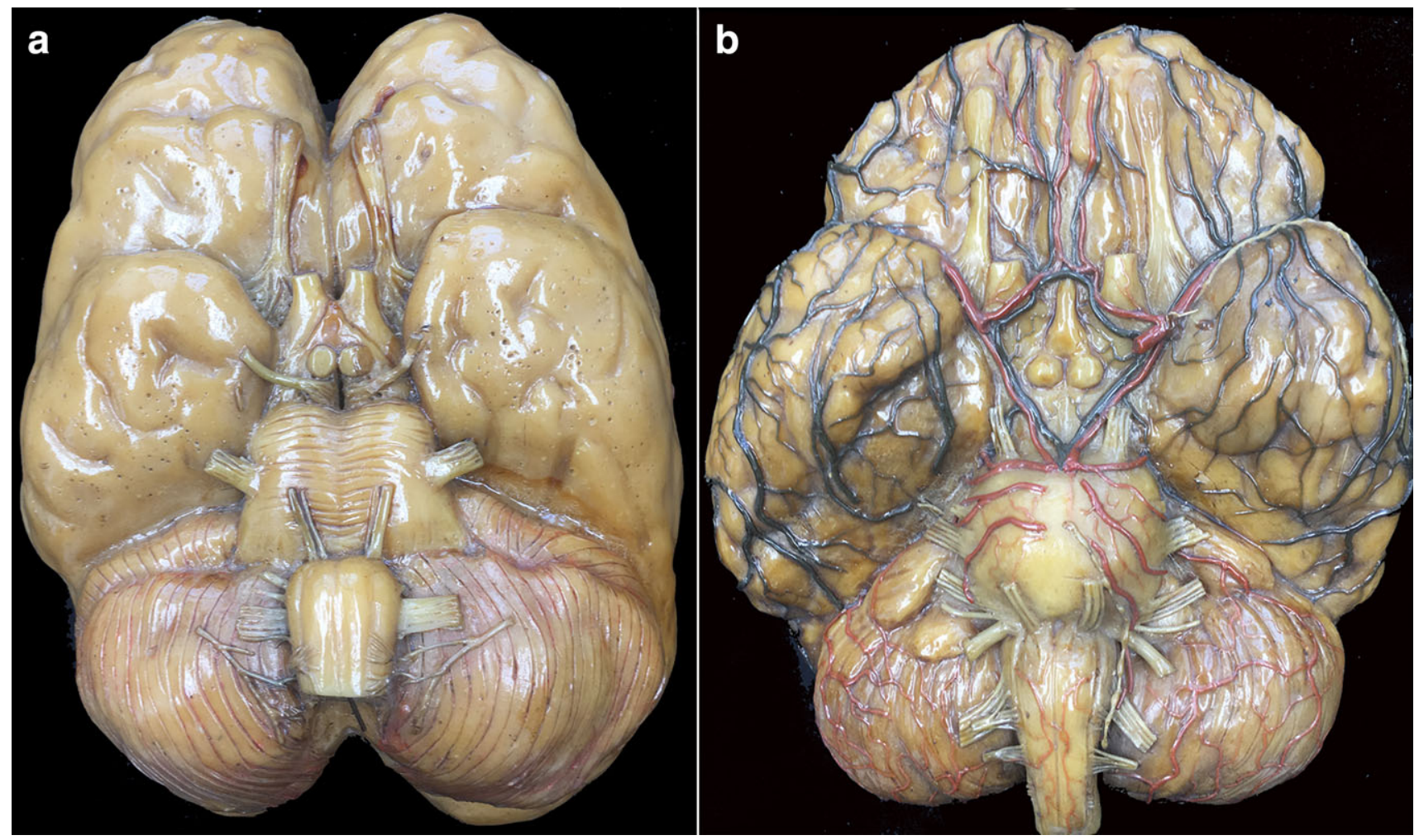

Fig. 2. Juan Cháez, Luigi Franceschi and Ignasi Lacaba. (a) basal aspect of the brain with the "apparent" origin and course of the twelve cranial nerves. (b) vascular relations of the cranial nerves. Polychrome wax sculpture of the end of the XVIII century. Royal College of Surgeons of Madrid, now "Museum Javier Puerta," Medical School, Complutense University of Madrid, Spain (MAJP00039; MAJP00040).

However, except for Thomas Willis's version, these proposals were not successful. Thomas Willis proposed a new classification composed of nine cranial pairs in his Cerebri anatome (1664) (Table 1). In it the I, II, III, IV, V, and VI



Fig. 3. Juan Cháez, Luigi Franceschi and Ignasi Lacaba. Sagittal section of the head to show the "apparent" origin and course of oculomotors nerves from the brain stem to the orbit. Polychrome wax sculpture of the end of the XVIII century. Royal College of Surgeons of Madrid, now "Museum Javier Puerta," Medical School, Complutense University of Madrid, Spain (MAJP00044). cranial nerves were those we recognize today; VII included the facial and vestibulocochlear nerves; VIII encompassed the glossopharyngeal and vagus nerves, and the cranial root of the accessory nerve; and IX consisted of the hypoglossal nerve and the spinal root of the accessory nerve (Table 1) (Arráez-Aybar et al., 2015). Willis's popularity helped to consolidate his new formula (Arráez-Aybar et al., 2015), which improved on earlier ones, and remained in place for more than 100 years until 1778, when Sömmerring in his Doctoral Dissertation formulated the current classification composed of 12 cranial pairs that, despite many disputes during the nineteenth century, has been accepted up to the present (Corrales et al., 2017).

However, we find different examples of the ambiguity of classification of the cranial nerves during the eighteenth and even the nineteenth century. In fact, due to the great popularity of Willis's work in England, some English books continued to use his formula until the end of the nineteenth century. Willis' influence also partially influenced Spanish anatomy. Indeed, in the universities there were considered to be 10 cranial nerves, following the descriptions of Willis: I, olfactory; II optic; III, oculomotor; IV, pathetic (trochlear); V, trigeminus; VI, indignatorio (abducens); VII, auditory; VIII, vagus; IX, gustative (hypoglossal); and X, suboccipital (Martínez, 1757) (Fig. 4); while in the Royal College of Surgery, teachers followed the descriptions of Vicq d'Azir (1776) that included 13 cranial nerves (Bonnels \& Lacaba, 1799) (Table 1).

New natural philosophies available in the earlier seventeenth and eighteenth centuries, such as the mechanicism 
of René Descartes (1596-1650) and Newton's mechanism, implied some important changes in anatomy. It was no longer anatomo-physiology. The link between function and structure was broken, and microscopic anatomy became more prominent than macroscopic anatomy. The rationality of medicine was now in microscopic structures (French, 1993, p 91-95). This new anatomy helped to elucidate new information about the cranial nerves, such as their real origin and their nuclei, as detailed below.

\section{Location of the Real Origin of the Cranial Nerves and their Nuclei}

The 12 cranial nerves (CNs) convey fibers coming from or going to their real nuclei of origin. The real origin of each cranial nerve has been classified based on the nature of their neurons into seven different modalities.

Four of the nuclei of the cranial nerves are afferent: (1) general sensory information (GSI); (2) special sensory

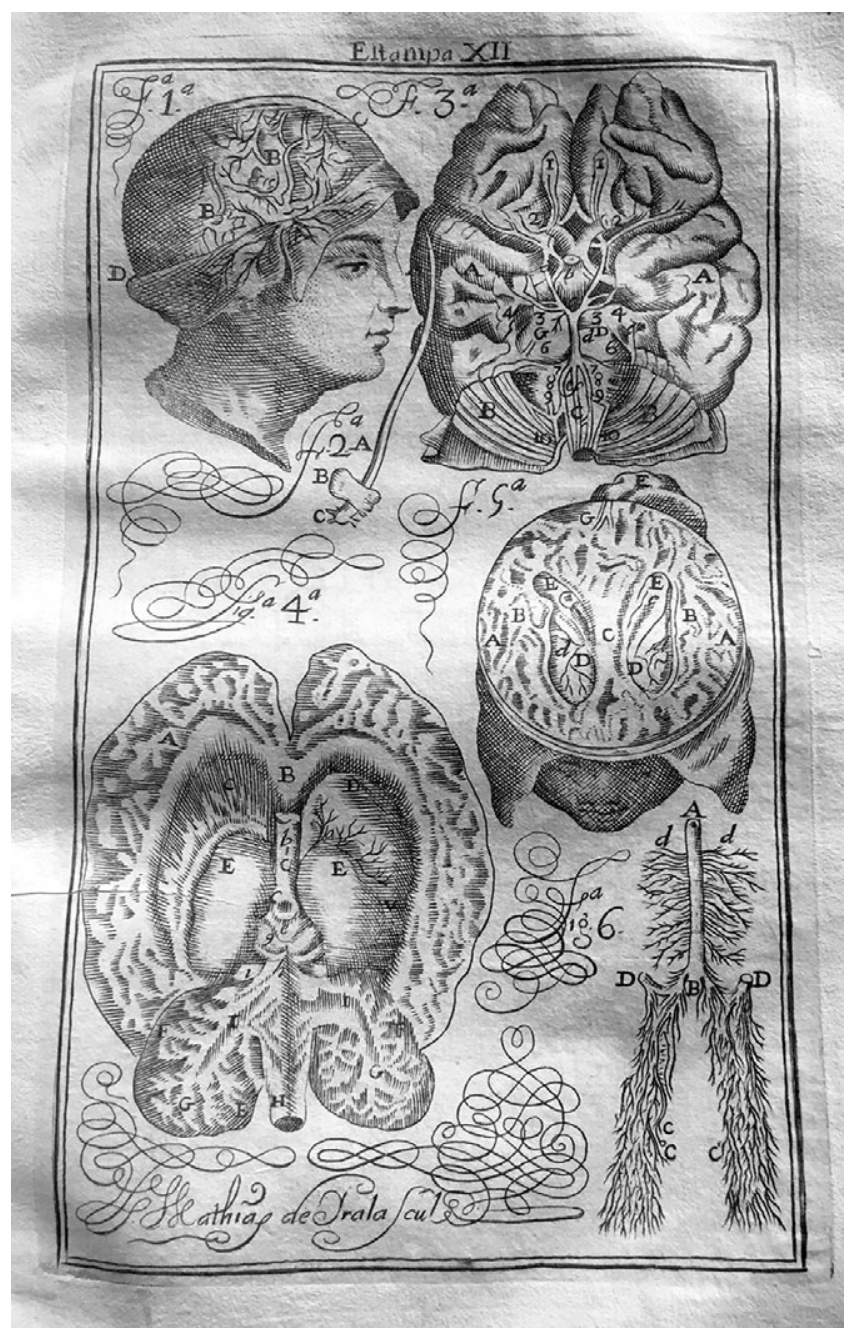

Fig. 4. Plate XII of the Martin Martinez's Book (1757) showing the central nervous system. In figure $3^{\mathrm{a}}$ it is possible to see in Arabic numbers nine cranial nerves following the description of Willis (1664). Martínez M. 1757. Anatomía Completa del hombre pp: 362-391. Madrid: Viuda de Jofeph de Orga.

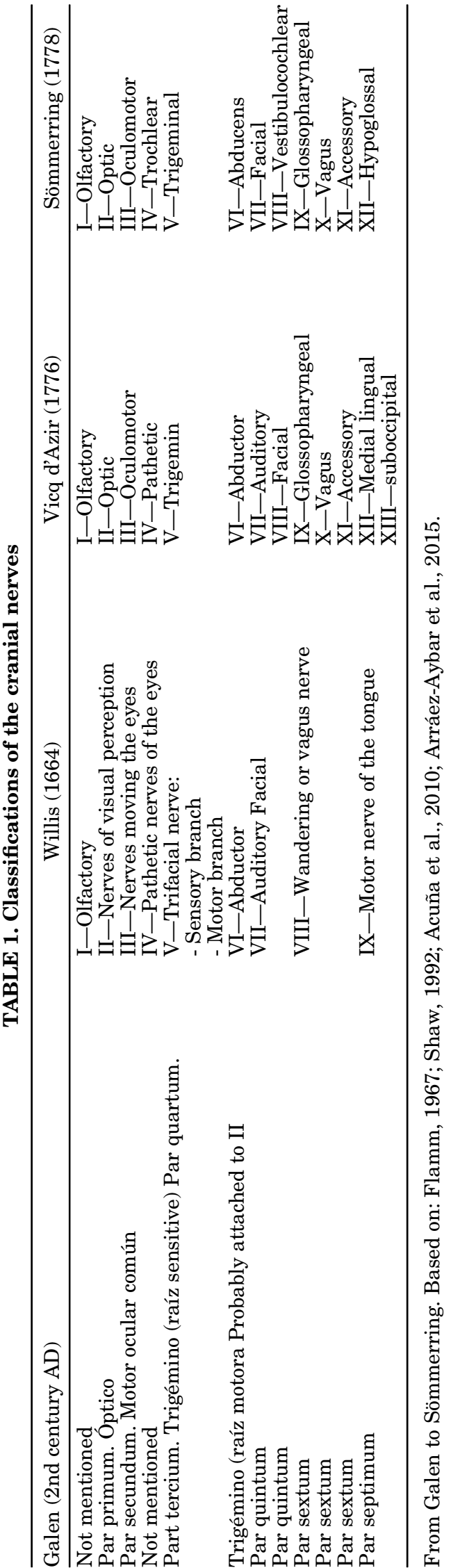




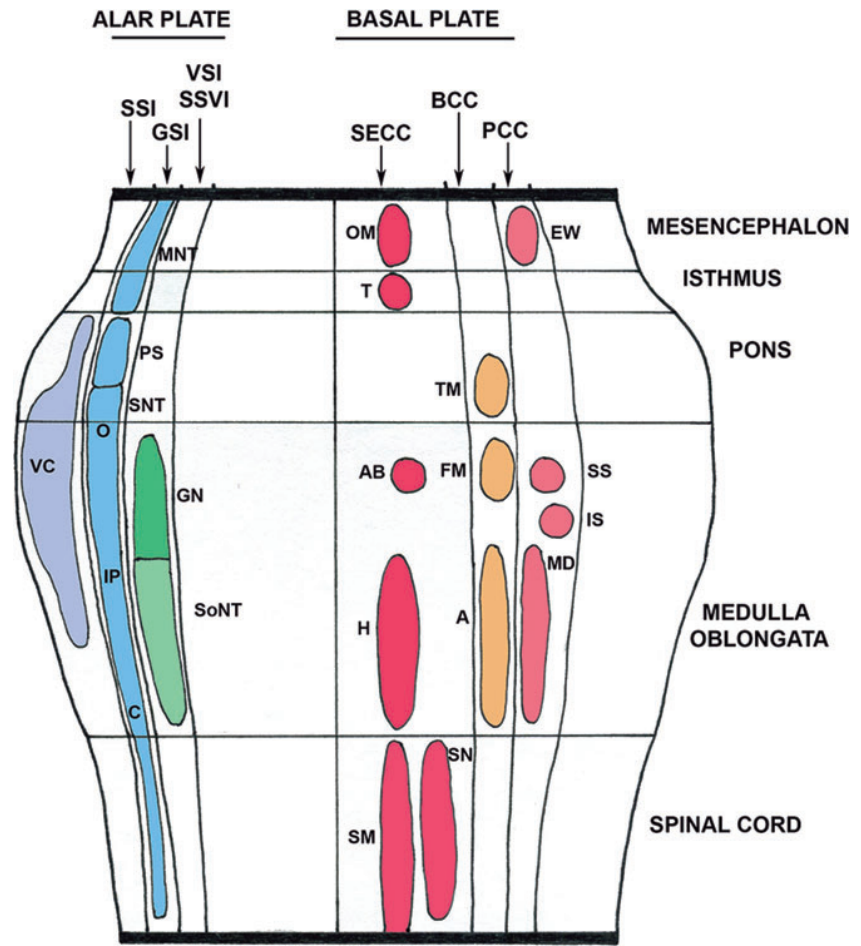

Fig. 5. Schematic representation of the brainstem showing the real origin of the cranial nerves. GSI: General sensory information. SSI: Special sensory information. VSI: Visceral sensory information. SSVI: Special sensory visceral information. SECC: Sopmatic eferent cell column. BCC: Branchiomotor cell column. PCC Parasympathetic cell column. A: Ambiguus nucleus (IX, $X$ and $X I$ cranial nerves $C N$ ). AB: Abducens nucleus (VI CN). EW: Edinger-Westphal nucleus (III CN). FN: Motor nucleus of the facial nerve (VII CN). GN: Gustatory nucleus (VII, IX and $X \mathrm{CN}$ ). H: Hypoglossal nucleus (XII CN). IP: Inferior salivatory nucleus (IX CN). MD: Dorsal motor nucleus of vagus (X NC). MNT: Mesencephalic nucleus and tract (V NC). OM: Oculomotor nuclei (III NC). PS: Principle sensory nucleus (V NC). SM: Spinal motoneurons. SN: Spinal nucleus $(X I N C)$. SNT: Spinal nucleus and tract (O: pars oralis. IP: pars interpolaris and C: pars caudalis) (V CN). SoNT: Solitary nuclei and tract (VII, IX and X CN). SS: Superior salivatory nucleus (VII $\mathrm{CN}$ ). T: Trochlear nucleus (IV CN). TM: Motor trigeminal nucleus (V CN). VC: Vestibulocochlear nuclei (VIII CN).

information (SSI); (3) visceral sensory information (VSI); (4) visceral special sensory information (SVSI); and three are efferent: (5) somatic efferent cell column (SECC); (6) brachiomotor cell column (BCC), (7) parasympathetic cell column (PCC) (Brodal, 1981; Williams, 1995) (Fig. 5).

CN 0, terminal nerve. This nerve was initially described in the dogfish shark by Fritsch (1878), (Larsell, 1950). This discovery gave rise to a number of discussions about nomenclature in subsequent years. Brookover (1914) and Johnston (1914) independently observed this nerve in human adults. Currently, this nerve is related to reproductive behavior (Schwanzel-Fukuda and Silverman, 1980).

CN I and CN II, olfactory and optic. They have their real origin located in the brain, but are not part of the central nervous system, although they have continued to appear in the list of cranial nerves for historical rather than scientific reasons (Williams, 1995).

CN III, oculomotor. This nerve carries fibers that have two real origins (SECC and PCC). Since the end of the nineteenth century the real origin of the SE fibers has
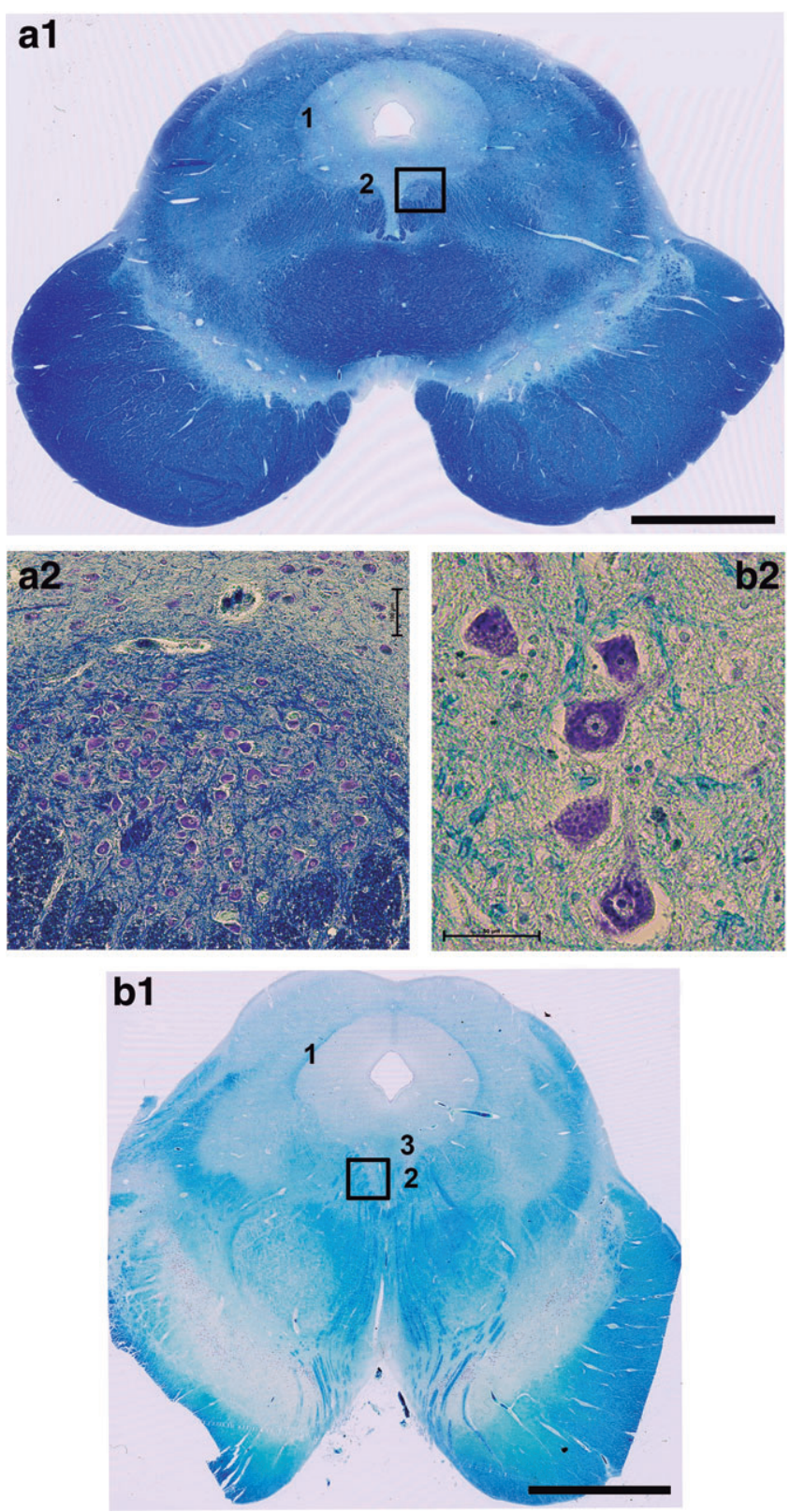

Fig. 6. Mesencephalon images stained according to the KlüverBarrera technique. a1) Horizontal section of the mesencephalon at the level of decussation of the superior cerebellar peduncles. Trigeminal mesencephalic nucleus and tract, 1. Trochlear nucleus, 2. Bar: $5 \mathrm{~mm}$. a2) Magnification of the area framed in a1. Trochlear nucleus motoneurons. Bar $100 \mu \mathrm{m}$. b1) Horizontal section of the mesencephalon in the caudal level of the upper colliculi. Trigeminal mesencephalic nucleus and tract, 1. Oculomotor nuclei, 2. Edinger-Westphal nucleus, 3. Apparent origin of the oculomotor nervous. Bar: $5 \mathrm{~mm}$. b2) Magnification of the area marked in b1. Oculomotor nucleus motoneurons. Bar: $100 \mu \mathrm{m}$. 
been identified in the mesencephalon nucleus of the oculomotor nerve. It is divided into a series of subnuclei dedicated to each particular extra ocular muscle (Bernheimer, 1897; Van Gehuchten 1898, Williams, 1995). The real origin of the PCC fibers surrounding the main nucleus is a complex population of nuclei: the Perlia, EdingerWestphal and Darkschewitsch nuclei (Ramón y Cajal, 1911). Of the above-mentioned nuclei the only one that was considered related to CN III was the EdingerWestphal nucleus that supplies the intraocular muscles (Brodal, 1981). It was a further century before the Perlia nucleus was included in the complex of CN III as a convergence center (Perlia, 1889, and Knies, 1891). Today we know that it is part of the subnuclei of the main nucleus (Warwick, 1955) (Fig. 6).

$C N I V$, trochlear. This nerve conveys fibers that have only one real origin (SECC). Some authors considered that its nucleus did not belong to the SECC because it was located more ventrally in the mesencephalon (Westphal and Siemerling, 1891; Boedecker, 1892). However, Ramón y Cajal (1911) and other authors showed that it was alienated from the other neurons of the column (Brodal, 1981; Williams, 1995). Another dispute related to this nerve was the course of their fibers. Some authors considered that they decussated (Van Gehuchten, 1898) and others that they did not, as has subsequently been demonstrated (Ramón y Cajal, 1911) (Fig. 6).

CN $\boldsymbol{V}$, trigeminal. This nerve conveys fibers that have only two different real origins (GS, BCC). The GS was considered as only one nucleus (Ramón y Cajal, 1895). However, later studies divided the nucleus into three different parts: oral, interoral and caudal (Mai and Paxinos, 2012). Subsequently, the chief sensory nucleus and the mesencephalic nucleus and tract were included (Brodal, 1981) (Figs. 6-8).

The BCC or masticatory nucleus is represented by two subnuclei: main and accessory (Ramón y Cajal, 1909). At the same time the masticatory was subdivided into two motor subnuclei (Szentágothai, 1949). The accessory nucleus initially considered as motor (Ramón y Cajal, 1909) was subsequently related to the proprioceptive afferent fibers and pseudopolar neurons (Allen, 1919; Clark, 1926; Weinberg, 1928, Sheinin, 1930). Now it is known as the mesencephalic nucleus of the trigeminal nerve, being the only nucleus of a $\mathrm{CN}$ with pseudopolar neurons (Johnston, 1909, May and Horsley, 1910, Thelander, 1924, Corbin, 1940, Pearson, 1949, Haines, 2012).

CN VI, abducens. This nerve conveys fibers from only one real origin (SECC). The nucleus is located in the pons, close to the facial nucleus that marks a prominence in the floor of the fourth ventricle known as the eminentia teres, or medial eminence (Ramón y Cajal, 1909; OrtsLlorca 1985). In different species some authors considered that this nucleus had another accessory nucleus: in the chicken (Van Gehuchten, 1898), rabbit (Lugaro, 1894) and humans (Pacetti, 1896). However, considerable research has been unable to find this accessory nucleus in humans (Van Gehuchten, 1903; Ramón y Cajal, 1909). Today we know that this accessory nucleus exists in several animals but not in primates (Cabrera et al., 1988). In the species that have this accessory nucleus it is associated with CN V and VII, and seems to be associated with the mechanism of ocular protection (Houston et al., 1979; Labandeira-García et al., 1987; Cabrera et al., 1988) (Fig. 7).

CN VII, facial and intermediate. This nerve conveys fibers from four different real nuclei origins (BCC, PCC, VSI, GSI) (Fig. 7). The BCC has its real origin as an elongated column of neurons located in the pons and extended between the rostral portion of the ambiguous nucleus and the superior olive (Ramón y Cajal 1895, 1909). Since early times it has been known that the facial nucleus is subdivided into different subnuclei (Marinesco, 1898, Marinesco 1899; Van Gehuchten, 1898; Papez, 1927; Szentágothai, 1949; Courville, 1966). One of the most animated discussions at the end of the nineteenth century was the possible existence of fibers that cross over between different courses (Lugaro, 1894; Van Gehutchen, 1898; Ramón y Cajal, 1909). Now is thought that the fibers do not have a crossover path (Brodal 1981, Williams 1995). Another strange debate was dedicated to justifying the loop of the fibers of the abducens nerve around the facial motor nucleus. It was proposed that it was mechanical (His, 1888), evolutionary (Ramón y Cajal, 1909) and embryological, due to motoneurons of the facial nerve emigrating from the fourth rhombomere to the sixth (Watson et al., 2012).

The VSI and GSI are carried in the intermediate nerve. The VSI comes from the geniculate ganglion to the upper part of the solitary tract, the gustatory nucleus (Williams, 1995), and the GSI joins with the fibers of CN IX and CN $\mathrm{X}$ to reach the caudal part or the solitary tract (Ramón $\mathrm{y}$ Cajal, 1909; Pearson, 1947).

The facial nerve also has an auricular cutaneous branch, whose bodies are in the geniculate ganglion (Larsell and Fenton, 1928). This branch closes in a similar way to that reported in the rat (Rhinehart, 1918). The real nucleus of origin of this component of the facial nerve is located in the descendent (spinal) nucleus of the trigeminal, and so also belongs to the GSI. Ramsay Hunt (1907) hypothesized the existence of those fibers based on the symptoms observed in patients with optic Herpes Zoster and neuralgia of the geniculate ganglion. Ramón y Cajal did not describe this component of the facial nerve (Ramón y Cajal, 1909).

The PCC real origin of the facial nerve was suspected after Miller's experiments (Miller, 1913). It was observed in a decapitated cat, provoking salivation after stimulation of the floor of the fourth ventricle (Miller, 1913). Posterior researchers showed that the salivatory nucleus is near to the facial nucleus (Kohnstomm, 1902, 1903; Kohnstomm and Wolfstein, 1907; Yagita, 1909; Yagita and Hayama, 1909). Äriens Kappers et al. (1936) found that a nucleus integrated in the parasympathetic cell column extended from the Edinger-Westphal nucleus in the mesencephalon to the dorsal vagus nucleus in the medulla oblongata. During the twentieth century the salivatory nucleus was defined among the reticular formation, and divided into two nuclei: the superior, associated with the facial, and inferior associated with the glossopharyngeal (Brodal, 1981).

CN VIII, vestibulocochlear. This nerve conveys fibers from two real nuclei of origin (SSI). It has two parts: vestibular and cochlear, and both belong to the SSI (Brodal, 1981) (Figs. 7 and 8). The vestibular nucleus was 

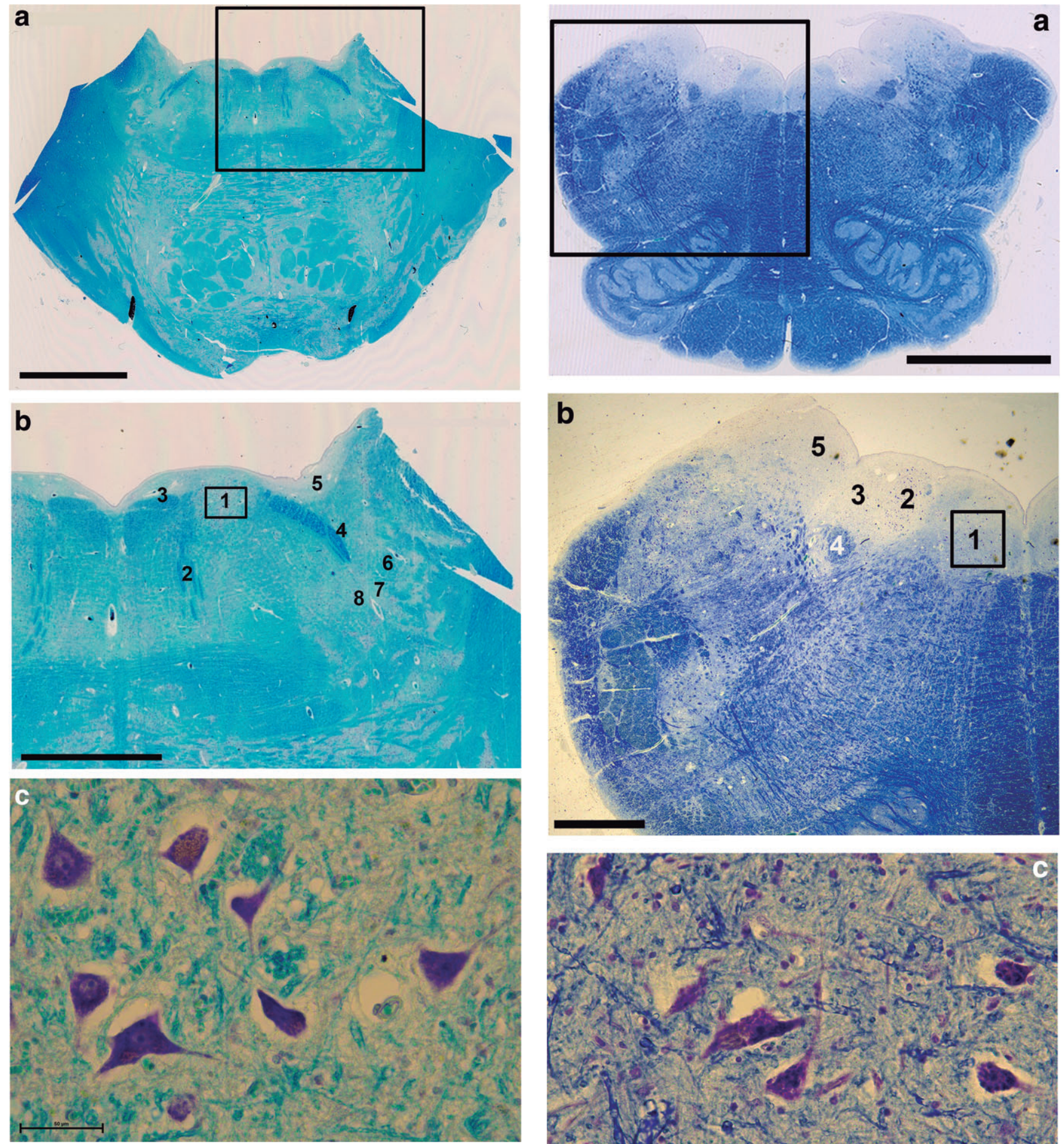

Fig. 7. Images of the bridge dyed according to the Klüver-Barrera technique. (a) Horizontal section of the bridge at the level of the knee of the facial nerve. Bar: $5 \mathrm{~mm}$. (b) Magnification of the area marked in a. Abducens nucleus, 1. Fibers of the abducens nervous, 2. Facial nerve knee, 3. Facial fibers, 4. Vestibular nuclei, 5. Spinal trigeminal tract, 6. Spinal trigeminal nucleus, 7. Motor nucleus of the facial nerve. 8. Bar: $3 \mathrm{~mm}$. (c) Abducens nucleus motoneuron and interneurons. Bar:50 $\mu \mathrm{m}$.

subdivided into four different subnuclei in the cat, and subsequently extended to humans (Brodal and Pompeiano, 1957). The four nuclei were: superior or

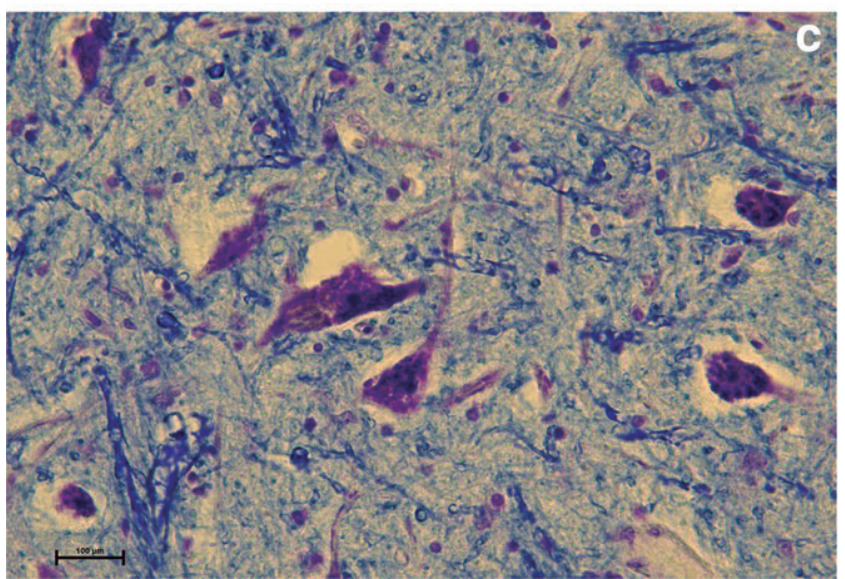

Fig. 8. Images of the medulla oblongata stained according to the Klüver-Barrera technique. (a) Horizontal section of the medulla oblongata made in the upper third of the inferior olive. Bar: $5 \mathrm{~mm}$. (b) Magnification of the area marked in a. Hypoglossal nucleus, 1. Motor dorsal nucleus of the vagus nerve, 2. Solitary nuclei, 3. Solitary tract, 4. Vestibular nuclei, 5. Spinal trigeminal tract, 6. Spinal trigeminal nucleus, 7. Bar: $3 \mathrm{~mm}$. (c) Magnification of the area marked in b. Hypoglossal nucleus motoneurons. Bar: $100 \mu \mathrm{m}$. 
Bechterew; dorsal or main; descendent; and Deiters' nucleus (Ramón y Cajal, 1897, 1909; Sabin, 1897; Äriens Kappers et al., 1936). The superior nucleus of Bechterew was discovered between 1885 and 1893, and was observed in different species: rat (Ramón y Cajal, 1909), rabbit (Messen and Olzewski, 1949), cat (Winkler and Potter, 1914) and humans (Sabin 1897; Jacobsohn, 1909; Marbourg 1910; Olzewski and Baxter, 1954). However, Von Kölliker (1896) [cited by Ramón y Cajal, 1909] considered the nucleus as a prolongation of the Deiters' nucleus. The inferior nucleus, the medial (Schwalbe's nucleus), the lateral (Dieters' nucleus) and the superior (Bechterew's nucleus) were comprehensively studied in humans by many authors such as Sabin (1897), Ramón y Cajal (1909), (Brodal and Pompeiano, 1957) and Messen and Olzewski (1949). The descending nucleus is characterized by the fact that it splits into fascicles of fibers, receiving the name of interstitial vestibular (Ramón y Cajal, 1909). Finally, it was shown that it is part of the Deiters' nucleus (Brodal and Pompeiano, 1957).

Initially two cochlear nuclei were described as ventral and lateral or acoustic tubercles (Ramón y Cajal, 1909; Williams, 1995). Nowadays the ventral nucleus bears the old name, and the lateral nucleus is referred to as dorsal, and forms a small protuberance called the acoustic tubercle in the lateral region of the floor of the fourth ventricle (Brodal, 1981). Santiago Ramón y Cajal's pupil Lorente de Nó described another nucleus, the nucleus lateralis cochlearis, consisting of a group of neurons that link both cochlear nuclei (cited by Orts-Lorca, 1985). Inside the ventral cochlear nucleus the neurons were organized tonotopically (Ramón y Cajal, 1909), as confirmed by Lorente de Nó (Larriva-Sahd, 2002) (Figs. 7 and 8).

CN IX and $X$, glossopharyngeal and vagus. These nerves share and convey fibers of four different real nuclei origins (BCC, PCC, VSI, GSI) (Fig. 8).

The VSI is located in the solitary tract, as in the case of the facial and intermediate nerves, in the upper part for taste and in the caudal part for the visceral sensory component (Pearson, 1947). Ramón y Cajal (1897) showed that some fibers of CN IX and X reached the spinal trigeminal tract and nucleus (GSI fibers). However, some researchers denied this (Van Gehuchten, 1900). Subsequent research confirmed that the $\mathrm{CN}$ IX and $\mathrm{X}$ carry fibers that have their real origin in the spinal tract of the trigeminal nerve (Brodal, 1947), at the same time that the solitary nucleus was found to be made up by a group of sub nuclei receiving visceral afferences from different regions (Nageotte, 1906; Mai and Paxinos, 2012).

The PCC. Until the end of the nineteenth century CN IX and $\mathrm{X}$ were associated with the dorsal nucleus of the vagus. However, different experiments showed that it is an exclusively vagal nucleus (Van Gehuchten, 1898; Ramón y Cajal, 1909).

The dorsal nucleus of the vagus was considered as sensory by eminent anatomists (Kölliker, quoted by Ramón y Cajal, 1909). It was Forel in 1891 who considered it to be a motor nucleus related to the roots of the vagus nerve; this was later confirmed by Marinesco (1899). It was also Marinesco who related the nucleus to the nerve supply of the smooth fibers of the digestive and respiratory systems (Marinesco, 1899) and not to the nerve supply of the larynx (Onuf and Collins, 1898; De Beule, 1902; Alfewstky,
1905). It was not until the twentieth century when the visceral motor component of the glossopharyngeal was assigned to the inferior salivary nucleus (Brodal 1981). Bechterew, Duval, Obersteiner, and Guden (cited by Ramón y Cajal, 1909) considered that a part of the motor fibers of CN IX and X came from another nucleus, different from the nucleus dorsal of the vagus. This nucleus was located between the fibers of the hypoglossal and the gelatinous substance of the trigeminal (spinal nucleus) that was known as the nucleus ambiguus (Ramón y Cajal, 1895). This nucleus was divided into cellular subgroups destined to innervate the musculature of the last pharyngeal arches (Ramón y Cajal, 1895; Brodal, 1981; Williams, 1995; Mai and Paxinos, 2012) (Fig. 8).

CN XI, accessory. This nerve shares and conveys fibers from one real nucleus of origin (BCC). At the end of the nineteenth century it was clear that the accessory nerve had two real origins: caudal, or medullar and cranial from the medulla oblongata (Ramón y Cajal, 1895). The medullar origin was firstly established by Roller (1881) and subsequently confirmed by Van Gehuchten (1900). Santiago Ramón y Cajal described the morphological characteristics of the nucleus (Ramón y Cajal, 1897). The cranial origin was located in the caudal part of the nucleus ambiguus, where it formed the origin of the fibers to the intrinsic muscles of the larynx (De Beule, 1902) (Fig. 8).

CN XII, hypoglossal. This nerve shares and conveys fibers from one real nucleus of origin (SECC). Stilling discovered the real origin of this CN in 1843 (Ramón y Cajal, 1909). Its motor nature is motor general somatic It is located on the floor of the fourth ventricle represented by the medial white wing (Ramón y Cajal, 1909; Williams, 1995). At the end of the nineteenth century it was thought that some few masses of neurons were related to it, such as the intercalated nucleus of Staderini, Roller and Duval, or accessory of the Hypoglossal. It was Ramón y Cajal who showed that these nuclei bore no relation to the hypoglossal (Ramón y Cajal, 1909), a fact that was later proved by other researchers (Brodal, 1981, 2016). Finally, it was shown that this nucleus was divided into several sub nuclei for each specific muscle of the tongue (Berkelbach, 1924) (Fig. 8).

\section{Nuclei and Genoarchitecture. The Last Step of the History of the Cranial Nerves}

It is now well accepted that our brain organization recovers the neuromeric brain models that explicitly incorporate brain segmentation as the fundamental AP partitioning principle (Puelles, 2018). The first seminal works regarding the analysis of a systematic morphology of vertebrate's brain was started by Wilhelm His in 1892-1893 (His, 1892). He first noticed the correlative topography of the notochord and named the floor plate of the neural tube pointing to the primary neural axis irrespective of the ulterior morphogenesis. He also first defined the lateral wall of neural tube with the terms from ventral to dorsal: basal (closer to floor plate), alar and roof plates (His, 1893) along the axis. Today the molecular biology and genetics has confirmed that hindbrain is patterned along the dorsoventral axis by the secretion of bone morphogenetic proteins (BMPs and 
dorsalin-1; sensory component effect) from the roof plate (Basler et al., 1993) and by the secretion of Sonic hedgehog (SHH; motor component effect) from the notochord and the floor plate (Marti et al., 1995).

Based on the inductive activity of these morphogens and others and a concert of many transcription factor, we can precisely state that in the basal plate of vertebrate hindbrain we can find 3 major columns: the somatic motor column (adjacent to the floor plate) with the motor nuclei of the III, IV, VI, and XII cranial nerves; the brachial motor column (more lateral) that innervate the voluntary muscles derived from the branchial arches (IX, X, and XI (ambiguous nucleus), and the motor nuclei of the $\mathrm{V}$ and VII). Finally, the third column is named the preganglionar parasympatic column (dorsal motor nucleus of the vagus (X), the inferior salivatory nucleus (IX), the superior salivatory nucleus (VII) and the accessory nucleus of the oculomotor complex (III)). These nuclei are located close to the ventricle, but lateral to the somatomotor column, close to the alar-basal boundary (Fig. 9; colored in red).

In the same manner the vertebrate's hindbrain alar plate distinguishes other three columns: (1) the viscerosensitive [general (sensations from the viscera) and special (taste sensation)] column; (2) somestetic sensitive, and (3) the special sensitive column. The viscerosensitive is composed by the solitary tract nucleus; its upper portion is specialized in receiving the taste information

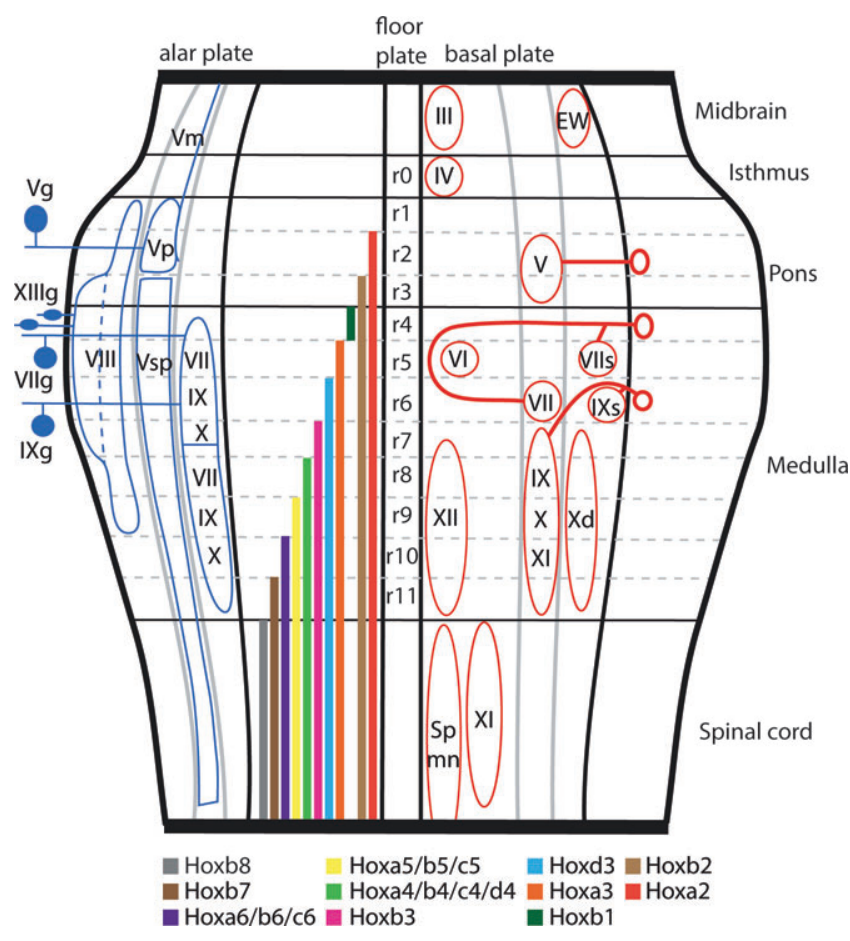

Fig. 9. Flat mount schematic representation of the midbrain, hindbrain and spinal cord showing the true topographic localization of cranial nerves depending on the longitudinal axis (from medial to lateral: floor plate, basal plate (in red) and alar plate (in blue) and depending on the transversal segmentation (the rhombomeres; $r 0-r 7$ and pseudo(crypto) rhombomeres; r8-r11). We have annotated the rhombomeric localization of the HOX family gene expression pattern profile depending of the rhombomeres (see also Tomás-Roca et al., 2016). (gustatory nucleus). It receives information from the VII, IX, and X cranial nerves. Then the somestetic sensitive column, which it is constituted by the sensitive nuclei of the $V$. It recollects the information from the face and neck. This nuclear complex also collects the somestetic information from the VII, IX and X cranial nerves. Finally, and most dorsal column (close to the tela choroidea) locates the special sensitive column composed by the vestibular and choclear nucleus (VIII cranial nerve. Fig. 9; colored in blue).

One of the surprising issues of historical brain segmentation is that Wilhem His never mentioned the word "neuromeres" in his works, neither did other major neuromorphologists such as Edinger and Ramón y Cajal, though the latter's pupil Tello $(1923,1934)$ did illustrate neuromeres in his neurofibrillary studies of chick and mouse embryos. Von Kupffer (1906) and Ziehen (1906) works summarized the early neuromeric results on all vertebrates. Nowadays, we have clear in mind that hindbrain is well delimited into transversal segments the "rhombomeres", which are visible in living embryos, and also in well-fixed material, mainly at early stages. The limiting constrictions later flattened out and disappeared correlatively with the thickening of the differentiating mantle layer.

In the 1990s the segment-like rhombomeres of the embryonic hindbrain, which had long been known as morphological entities, were found to be lineage-restricted compartments. In the rhombomeres, the neuronal populations produced in each of them appear in a repetitive way, indicating a metameric subdivision. So, rhombomeres are indeed developmental units that each produce specific portions in the mature hindbrain. So, these segments will give rise to the isthmic segment, a group of seven rhombomeres (r1-r7) and four pseudorhombomeres (r8-r11) (Cambronero and Puelles 2000; Fig. 9). These last segments cannot be delimitated macroscopically, as the rhombomeres, but share with them molecular and histogenetics limits.

The recent concept of neural genoarchitecture examines from several angles the rationale for this new approach in causal and descriptive neuroanatomy. Gene expression patterns can be used as topographic stains revealing architectonic borders that may clarify, dispute, or complicate existing brain anatomical subdivisions based on other methods, while increasing our understanding of how they arise in ontogenesis and evolution (Puelles and Ferran, 2012). We are now in pose to write that true cranial nerves are associated within the hindbrain with the exception of the III-CN which is located in the midbrain. Each cranial nerve has its own characteristic composition of fibers. The mixed nerves present a unique root located in the alar plate. The arrival of the sensitive afferences attracts the axons from the branchiomotor and parasympatic preganglionar neurons. Therefore, the position of the sensitive ganglia decides the location of the mixed nerve roots. This position is located in the even rhombomeres, V ganglion in r2, VII/VIII ganglion in $\mathrm{r} 4$, IX ganglion in $\mathrm{r} 6$ and the $\mathrm{X}$ ganglion in diverse pseudorhombomeres (Kiecker and Lumsden, 2005). Nevertheless, all the mixed nerves have efferent elements in at least two consecutives segments, neurons in $\mathrm{r} 2$ and $\mathrm{r} 3$ compose the V-CN nucleus, in $\mathrm{r} 4$ and $\mathrm{r} 5$ the VII-CN nucleus, in $\mathrm{r} 6$ and $\mathrm{r} 7$ the IX-CN nucleus, in $\mathrm{r} 7$ to r10 the X-CN nucleus and in r11 the XI-CN nucleus. The 
efferent axons from the odd segments grow first in to the alar plate and then rostrally to exit the hindbrain in the root of the adjacent segment. The pure motor cranial nerves nuclei are located in specific segments and closed to the midline (given by the morphogenetic ventralizing activity of SHH (Briscoe et al., 2000). These cranial nerves are the III in the midbrain, the IV in the isthmus (r0), the VI in r5 and the XII in r8 to r11 (Marin and Puelles, 1995; Cambronero and Puelles 2000).

Hox family genes are expressed in the hindbrain in a nested fashion and their borders of expression coincide with rhombomere boundaries (Wilkinson et al., 1989), much like their nested expression in the $D$. melanogaster embryo during the regulation of segmental identity. Thus, the positional identity of each segment is defined by the combinatorial expression of the Hox genes. For example, Hoxb1, a gene that is uniquely expresses in a single rhombomere, $r 4$. This rhombomere shows characteristics of $\mathrm{r} 2$ in Hoxb1-deficient mice; specifically, facial motor neurons born in $\mathrm{r} 4$ fail to migrate caudally into r6 and vestibuloacoustic neurons fail to migrate to the contralateral side of $\mathrm{r} 4$. Instead, both types of neuron migrate dorsolaterally like the r2-specific trigeminal motor neurons (Studer et al., 1996). Conversely, ectopic expression of HOXB1 in the 2 of chick embryos leads trigeminal motor neurons to adopt R4-like characteristics and project into the second branchial arch, like the normal facial motor neurons of $\mathrm{r} 4$ (Bell et al., 1999). These studies indicate that Hoxb1 specifies aspects of $\mathrm{r} 4$ identity in a selector gene-like fashion: both removal of the selector from its segment and ectopic expression in another segment result in homeotic transformations in which one segment adopts the phenotype of the other. Similarly, facial and trigeminal-like neurons can be induced in $\mathrm{r} 1$, which is normally devoid of motor neurons, following ectopic expression of HOXB1 and HOXA2, respectively (Jungbluth et al., 1999). Together, these findings indicate that the embryonic hindbrain satisfies the criteria for a segmented structure: the continuous neuroepithelium is subdivided into transverse cell lineage-restricted compartments that are serially arrayed along its anteroposterior axis and the positional identity of which is regulated, at least in part, by the differential expression of selector Hox genes (Fig. 9; see also Tomás-Roca et al., 2016).

\section{Literature Cited}

Acuña M, Folgeuira A, Sinagra A, Pérez M, Larrarte G, Conesa HA. 2010. Aspectos históricos sobre los nervios craneales. Rev Argent Neuro 24:41-48.

Alfewstky N. 1905. Les noyaux sensitifs et moteurs du nerf vague chez le lapin. Le neuroaxe 7:23-27.

Allen WF. 1919. Application of the Marchi method to the study of the radix mesencephalica trigemini in the Guinea pig. J Comp Neurol 30:169-216.

Äriens Kapper CU, Huber GL, Crosby EC. 1936. The comparative anatomy of the nervous system of vertebrates, including man. New York: McMillan.

Arráez-Aybar L-A, Navia-Álvarez P, Fuentes-Redondo T, Bueno-López J-L. 2015. Thomas Willis, a pioneer in translational research in anatomy (on the 350th anniversary of Cerebri anatome). J Anat 226:289-300.

Basler K, Edlund T, Jessell TM, Yamada T. 1993. Control of cell pattern in the neural tube: Regulation of cell differentiation by dorsalin-1, a novel TGF beta family member. Cell 73:687-702.
Bell E, Wingate RJ, Lumsden A. 1999. Homeotic transformation of rhombomere identity after localized Hoxb1 misexpression. Science 284(5,423):2168-2171.

Berkelbach H. 1924. The hypoglossal nerve in an embryo of Erinaceus europeus. J Comp Neurol 36(3):219-269.

Bernheimer S. 1897. Experimentelle Studien zur Kenntniss der Innervation der inneren und äusseren vom Oculomotorius versorgten Muskeln des Auges. V Graefes Arch Ophtal 44:481-525.

Boedecker J. 1892. Über einen Fall von chronischer progressiver Augenmuskellähmung. Arch Psychiat Nervenkr 23:313-338.

Bonnels J, Lacaba I. 1799. Curso Completo de Anatomía del cuerpo Humano, Vol. IV. Madrid: Imprenta de Sancha. p 68-137.

Briscoe J, Pierani A, Jessell TM, Ericson J. 2000. A homeodomain protein code specifies progenitor cell identity and neuronal fate in the ventral neural tube. Cell 101(4):435-445.

Brodal A. 1947. Central course of afferent fibers for pain in facial, glossopharingeal and vagus nerves. Clinical observations. Arch Neuropsychol 57(3):292-306.

Brodal A. 1981. Neurological anatomy in relation to clinical medicine. 3rd ed. Oxford: Oxford University Press.

Brodal P. 2016. The central nervous system. 5th ed. Oxford: Oxford University Press.

Brodal A, Pompeiano O. 1957. The vestibular nuclei in the cat. J Anat 91:438-454.

Brookover C. 1914. The nervus terminalis in adult man. J Comp Neurol 24:131-135.

Cabrera B, Portillo F, Pásaro R, Delgado-García JM. 1988. Location of motoneurons and internuclear neurons within the rat abducens nucleus by means of horseradish perxidase and fluorescent soluble labeling. Neurosci Lett 87:1-6.

Cambronero F, Puelles L. 2000. Rostrocaudal nuclear relationships in the avian medulla oblongata: a fate map with quail chick chimeras. J Comp Neurol 427:522-545.

Clark SL. 1926. Nissl granules of primary afferent neurons. J Comp Neurol 41:423-451.

Corbin KB. 1940. Observations on the peripheral distribution of fibers arising in the mesencephalic nucleus of the fifth cranial nerve. J Comp Neuro 73(1):152-177.

Corrales CE, Mudry A, Jackler RJ. 2017. Perpetuation of errors in illustration of cranial nerve anatomy. J Neurosurg 127:192-198.

Courville J. 1966. The nucleus of the facial nerve: The relation between cellular groups and peripheral branches of the nerve. Brain Res 1(4):338-354.

De Beule F. 1902. Recherches expérimentales sur l'innervation du larynx chez le lapin. Le Neuroaxe 4:163-220.

Fallopius G. 1561. Observationes anatomicae. Venice: Marco Antonio Ulomo and Gratioso Perchachino.

Flamm ES. 1967. Historical observations on the cranial nerves. J Neurosurg 27(4):285-297.

French R. 1993. The anatomical tradition. In: Bynum WF, Porter R, editors. Companion encyclopedia of the history of medicine, Vol. 1. London: Routledge. p 81-101.

García Ballester L. 1972. Galeno en la sociedad y en la ciencia de su tiempo. Madrid: Eds. Guadarrama.

García Ballester L. 1974. De la anatomía alejandrina al "Corpus Galineaum". Medicina e Historia ( $2^{\text {a }}$ época) 37:7-26.

Haines D. 2012. Fundamental neuroscience for basic and clinical applications. 4th ed. Philadelphia, PA: Saunders.

His W. 1888. Zur Geschichte des Gehirns sowie der centralen und periferischen Nervenbahnen beim menschlichen Embryo. Abh Math Phys Kl Kgl Säch Ges Wiss 14:339-393.

His W. 1892. Zur allgemeinen Morphologie des Gehirns. Arch Anat Entwickl-Gesch 2:346-383.

His W. 1893. Vorschläge zur Eintheilung des Gehirns. Arch Anat Entwickl-Gesch Jahrg 3:173-179.

Hutson KA, Glendenning KK, Masterton RB. 1979. Accessory abducens nucleus and its relationship to the accessory facial and posterior trigeminal nuclei in cat. J Comp Neurol 188:1-16.

Jacobsohn L. 1909. Über die Kerne des menschlichen Hirnstamms. Abh Kön Preuss Akad Wiss Physik Math Kl:1-70.

Johnston JB. 1909. The radix mesencephalica trigemini. J Comp Neurol 19:593-644. 
Johnston JB. 1914. The nervus terminalis in man and mammals. Anat Rec 8:185-198.

Jungbluth S, Bell E, Lumsden A. 1999. Specification of distinct motor neuron identities by the singular activities of individual Hox genes. Development 126(12):2751-2758.

Keele KD. 1961. Three Early Masters of Experimental MedicineErasistratus, Galen and Leonardo Da Vinci. Proceedings of the Royal Society of Medicine 54:577-588.

Kiecker C, Lumsden A. 2005. Compartments and their boundaries in vertebrate brain development. Nat Rev Neurosci 6(7): $553-564$.

Knies M. 1891. Über die centralen Störungen der willkürlichen Augenmuskeln. Arch Augenheilk 23:19-51.

Kohnstamm O. 1902. Der Nucleus salivatorius chordae tympani (nervi intermedii). Anat Anz 21:362-363.

Kohnstamm O. 1903. Der Nucleus salivatorius inferior und des cranio-viscerale system. Neurol Zentralbl 22:699.

Kohnstamm O, Wolfstein J. 1907. Versuch einer physiologischen Anatomie der Vagusursprünge und des Kopfsympatheticus. J Psycol U Neurol Bd 8:177-203.

Labandeira-García JL, Guerra-Seijas MJG, Segad LAG, Suarez-Núñez JM. 1987. Identification of abducens motoneurons, accessory abducens motoneurons, and abducens internuclear neurons in the chick by retrograde transport of horseradish peroxidase. J Comp Neurol 259:140-149.

Laín Entralgo P. 1978. Historia de la medicina. Barcelona: Salvat.

Larriva-Sahd J. 2002. Some contributions to Rafael Lorente de Nó to neuroscience: A reminiscence. Brain Res Bull 39(1):1-11.

Larsell O. 1950. The nervus terminalis. Ann Otol Rhinol Laryngol 59:414-438.

Larsell O, Fenton RA. 1928. The embryology and neurohistology of the sphenopalatine ganglion connections: A contribution to the study of otalgia. Laryngoscope (St Louis) 38:371-389.

López Salvá M. 2002. Galeno. Procedimientos anatómicos. Libros I-IX. Introduction, Comments and translation into Spanish. Madrid: Gredos.

Lugaro E. 1894. Sull'origine di alcuni nervi encefalici. Arch Ottamol 5:181-186.

Macchi V, Porzionato A, Morra A, De Caro R. 2014. Gabriel Fallopius (1523-1,562) and the Facial canal. Clin Anat 27:4-9.

Mai JK, Paxinos G. 2012. The human nervous system. 3rd ed. San Diego-Amsterdam: Academic Press.

Mandressi R. 2003. Le regard de l'anatomiste. Dissections et invention du corps en Occident. Paris: Éditions du Seuil.

Marbourg O. 1910. Mikroskopisch-topographischer Atlas des menschlichen Zentralnervensystems. Leipzig und Wien: Franz Deuticke.

Marín F, Puelles L. 1995. Morphological fate of rhombomeres in quail/chick chimeras: A segmental analysis of hindbrain nuclei. Eur J Neurosci 7:1714-1738.

Marinesco G. 1898. L'origine du facila supérieur. Rev Neur 6:30.

Marinesco G. 1899. Nouvelles recherches sur l'origine du facial supérieur et du facial inferieur. Presse Med 65:85-88.

Marti E, Takada R, Bumcrot DA, Sasaki H, McMahon AP. 1995. Distribution of sonic hedgehog peptides in the developing chick and mouse embryo. Development 121:2537-2547.

Martínez M. 1757. Anatomía Completa del hombre. Madrid: Viuda de Jofeph de Orga. p 362-391.

May O, Horsley U. 1910. The mesencephalic root of the fifth nerve. Brain 33:175-203.

Meessen H, Olzewski J. 1949. A cytoarchitectonic atlas of the rhombencephalon of the rabbit. Basel und Wien: Franz Deuticke.

Miller FR. 1913. On the reactions of the salivary centers. Q J Exp Physiol 6:57-72.

Nageotte J. 1906. The pars intermedia or nervus intermedius of Wrisberg and the bulbopontine gustatory nucleus in man. Rev Neurol Psych 4:473-488.

Olzewski J, Baxter D. 1954. Cytoarchitecture of the human brainstem. New York: S. Karger.

Onuf B, Collins J. 1898. Experimental researches on the localisatiuons of the sympathetic nerve in the spinal cord and brain, and contributions to its physiology. J Nerv Ment Dis 25(9):661-678.
Orts-Llorca F. 1985. Anatomía Humana. Tomo II. 6th ed. Madrid: Editorial Científico Médica.

Pacetti G. 1896. Sopra il nucleo di origine dell nervus abducens. Ric. f. ncl. Laboratorio d'Anat, norm. Di Roma 5:121-133.

Papez JW. 1927. Subdivisions of the facial nucleus. J Comp Neurol 43:159-191.

Pearson A. 1947. The root of the facial nerve in the human embryos and fetuses. J Comp Neurol 87:139-159.

Pearson AA. 1949. The development and connections of the mesencephalic root of the trigeminal nerve in man. J Comp Neurol 90:1-46.

Perlia R. 1889. Die anatomie des oculomotoriuscentrums beim menschen. V Graefes Arch Ophtal 35:287-304.

Porzionato A, Macchi V, De Caro R. 2013. The role of Caspar Bartholin the Elder in the evolution of the terminology of the cranial nerves. Ann Anat 195:28-31.

Puelles L. 2018. Developmental studies of avian brain organization. Int J Dev Biol 62(1-3):207-224.

Puelles L, Ferran JL. 2012. Concept of neural genoarchitecture and its genomic fundament. Front Neuroanat 6:47.

Ramón y Cajal S. 1895. Apuntes para el estudio del bulbo raquídeo, cerebelo y origen de los nervios craneales. Anales de la Sociedad Española de Historia Natural. Serie II. Tomo Cuarto (XXIV):1-118.

Ramón y Cajal S. 1897. Nueva contribución al estudio del bulbo raquídeo: VII Estudio del núcleo de Roller y del extremo superior del asta anterior de la médula. Revista Trimestral de Micrografía 2:94-99.

Ramón y Cajal S. 1909. Histologie du Système Nerveux de l'Homme et des Vertébrés. tome I. Paris: Maloine.

Ramón y Cajal S. 1911. Histologie du Système Nerveux de l'Homme et des Vertébrés. tome II. Paris: Maloine.

Ramsay Hunt J. 1907. On herpetic inflammations of the geniculate ganglion. A new síndrome and its complications. J Nerv Ment Dis 34:73-96.

Rhinehart A. 1918. The nervus facialis of the albino mouse. J Comp Neurol 30:81-125.

Roller CFW. 1881. Der centrale verlauf des nervus glossopharyngeusder nucleus lateralis medius. Arch Mikroskop Anat 19:347-383.

Sabin FR. 1897. On the anatomical relations of the nuclei of reception of the cochlear and vestibular nerves. Johns Hopkins Hosp Bull 8:253-259.

Savage Smith E. 1971a. Galen's account of the cranial nerves and the autonomic nervous system, part 1. Clio Med 6:77-98.

Savage Smith E. 1971b. Galen's account of the cranial nerves and the autonomic nervous system, part 2. Clio Med 6:173-194.

Schwanzel-Fukuda M, Silverman AJ. 1980. The nervous terminalis of the guinea pig: A new luteinizing hormone-releasing hormone (LHRH) neuronal system. J Comp Neurol 191:213-225.

Shaw JP. 1992. A history of the enumeration of the cranial nerves by European and British anatomists from the time of Galen to 1895 with comments on nomenclature. Clin Anat 5:466-484.

Sheinin JJ. 1930. Typing of the cells of the mesencephalic nucleus of the trigeminal nerve in the dog, based on Nissl-granule arrangement. J Comp Neurol 50:109-131.

Singer C. 1957. A short history of anatomy \& physiology from Greeks to Harvey. New York: Dover Publications. p 56-57.

Sonig A, Thakur J, Grass M, Khan IS, Ghandi V, Nanda A. 2013. Antonius Balthazar Raymundus Hirsch and the peregrination of "gasserian ganglion". J Neurosurg 119:778-784.

Studer M, Lumsden A, Ariza-McNaughton L, Bradley A, Krumlauf R. 1996. Altered segmental identity and abnormal migration of motor neurons in mice lacking Hoxb-1. Nature 384(6,610):630-634.

Szentágothai J. 1949. Functional representation in the motor trigeminal nucleus. J Comp Neurol 90:111-120.

Tello JF. 1923. Les différenciations neuronales dans l'embryon de poulet, pendant les premiers jours de l'incubation. Trab Lab Invest Biol 21:1-94.

Tello JF. 1934. Les differenciations neurofibrilaires dans le prosencephale de la souris de 4 à 15 millimètres. Trab Lab Invest Biol 29: 339-396.

Temkin O, Temkin CL, editors. 1967. Ancient medicine: Selected papers of Ludwig Edelstein. Baltimore: The Johns Hopkins Press. 
Thelander HE. 1924. The course and distribution of the radix mesencephalica trigemini in the cat. J Comp Neurol 37:207-220.

Tomás-Roca L, Corral-San-Miguel R, Aroca P, Puelles L and, Marín F. 2016. Crypto-rhombomeres of the mouse medulla oblongata, defined by molecular and morphological features. Brain Struct Funct 221(2):815-838.

Tubbs S, Padmalayam D, Shoja MM, Loukas M. 2014. Heinrich August Wrisberg (1736-1808) physician and anatomist. Clin Anat 27:10-13.

Van Gehuchten A. 1898. Recherches sur l'origine réelle des nerfs crâniens. I Les nerfs moteurs oculaires. J Belg Neurol 3:114-129.

Van Gehuchten A. 1903. Recherches sur l'origine réelle et le trajet intracérébral des nerfs moteurs. Le Néuroaxe 5:265-337.

Vesalius A. 1997. De Humani Corporis Fabrica. Spanish translation of the original (1543). Aranjuez: Doce Calles.

Von Kölliker A. 1896. Handbuch der Gewebelehre des Menschen, Vol. 2. 6th ed. Leipzig: W. Englemann. p 293-300.

Von Kupffer K. 1906. Die Morphogenie des Centralnervensystems. In: Hertwig $\mathrm{O}$, editor. Handbuch der vergleichenden und experimentellen entwicklungslehre der wirbeltiere, Part III, Vol. 2. Jena: Fischer. p 1-272.

Walshe TM. 2016. Neurological concepts in Ancient Greek Medicine. Oxford: Oxford University Press.

Warwick R. 1955. The so-called nucleus of convergence. Brain 78(1): 92-144.
Watson C, Paxinos G, Puelles L. 2012. The mouse nervous system. 1st ed. San Diego, CA: Academic Press.

Weinberg E. 1928. The mesencephalic root of the fifth cranial nerve: A comparative anatomical study. J Comp Neurol 46:249-405.

Westphal CFO, Siemerling E. 1891. Ueber die chronische progressive Lähmung der Augenmuskeln. Basel: Archiv f. Psychiatrie. Supplement.

Wilkinson DG, Bhatt S, Cook M, Boncinelli E, Krumlauf R. 1989. Segmental expression of Hox-2 homoeobox-containing genes in the developing mouse hindbrain. Nature 341(6241):405-409.

Williams PL. 1995. Gray's anatomy: The anatomical basis of medicine and surgery. 38th ed. Philadelphia, PA: Churchill Livingstone.

Winkler C, Potter A. 1914. An anatomical guide to experimental researches on the cat's brain. A series of 35 frontal sections. Amsterdan: W. Verluys.

Yagita K. 1909. Weitere Untersuchungen über das Speichelzentrum. Anat Anz 35:70-75.

Yagita K, Hayama S. 1909. Über des Speichelsekretions-centrum. Neuro Zbl 28:738-753.

Ziehen T. 1906. Die morphogenie des zentralnervensystems der säugetiere. In:Hertwig $\mathrm{O}$, editor. Handbuch der vergleichenden und experimentellen Entwicklungslehre der Wirbeltiere, Vol. 2. Jena: Fischer. p 273-368. 